\title{
A NEW "OPEN BUDGET SYSTEM" IN UZBEKISTAN TO ENSURE TRANSPARENCY IN THE BUDGET SYSTEM
}

\author{
Najmiddinov Yahyo Fazliddin o'gli \\ Second-year master's degree student of Tashkent State University of Economics, Tashkent, \\ Uzbekistan
}

Article DOI: https://doi.org/10.36713/epra9615 DOI No: 10.36713/epra9615

\section{ANNOTATION}

The introduction of fiscal policy transparency practices in the contemporary local financial management system is one of the prerequisites for increasing the socio-economic development of regions. Creating a transparent budget environment contributes to a faster and more effective solution to the region's current problems. The lack of a sufficient level of budgetary transparency is a consequence of poor public interest consideration, which impedes the realization of their own democratic aspirations and freedoms. This article is aimed to look through the importance of budget transparency and its good effects on the budgetary system. The public finance transparency assessment of Uzbekistan has shown that its population needs a higher level of information disclosure, use of the latest information channels, and the creation of convenient forms of involvement in the budget process. The transparency evaluation results in the areas of budgeting, public procurement, disposal of property of the territorial community, etc. have been investigated. Besides, directions for improving Uzbekistan's local authorities' information policy are proposed to increase its transparency.

KEYWORDS: Budget system, budget transparency, local budget, local budget indicators, fiscal policy, budgetary system, open budget system.

\section{INTRODUCTION}

Given the economic processes that have taken place in recent times and the emphasis on improving the economic well-being of the population, each country has been trying to increase the transparency of its budget system and the heating and importance of the people of its own state to the economic situation of its state. There have also been a number of attempts in our country to increase the importance of the economic concept, which has been called the "Open Budget Policy" for many years. To be more precise we can count many laws and decisions which have been made by our President and Ministry bodies. The importance of an open budget policy is enormous in the country's macroeconomic conditions and in the social and economic development of local governments and provinces and cities.

Overcoming the disparities of regional development is also in the area of budget information transparency, public participation in the budget process, the creation of mechanisms for public control over the spending of budget funds. The implemented principles of budgetary transparency bring the domestic budgetary system closer to international standards and increase public confidence in the reforms.

\section{LITERATURE REVIEW}

Ensuring the openness and transparency of the country's budget system is one of the most profound factors affecting the development of the economy. As a result of their research, foreign economists have commented on this.

In January 1998, George Kopits and John Craig published an article entitled 'Transparency in Government Operations' (Kopits and Craig, 1998). They created a turning point in understanding financial transparency. Their argument was direct: the timely publication of a clearly presented budget document (ie transparency) allows the market to assess the intentions of the government and provides the key to compliance with market discipline by the government, despite the fact that this argument increased the political risks of functioning politicians in the context of managing an unstable economy. 
Since the beginning of the new century, many economists have begun to search for factors that influence changes in fiscal transparency. Such attempts were made by Alt et al. (2002; 2006), which noted the importance of institutional and financial factors. In the studies of A. Styles and M. Tennyson, economic factors such as the size of the municipality, population, per capita income, and accounting disclosure, based on the analysis of financial reports of 300 US municipalities, were noted (Styles \& Tennyson, 2007).

As we mentioned before President of Uzbekistan also has discussed budgetary transparency in Uzbekistan. As a clear indication of this, on the

"Action Strategy for the five priority areas of development of the Republic of Uzbekistan in 20172021" specifically mentioned this. [1] It should also be noted that in the framework of reforming the country's economy, consistent work is being done to expand access to economic and financial statistics and introduce new mechanisms to increase the transparency of the budget process.

As a practical expression of the decision, today in our country the internet portal "Open budget. uz" [2] operates.

An open budget is a government policy aimed at shaping available information so that citizens have an understanding of budgets at different levels. The Ministry of Finance of the Republic of Uzbekistan has been actively developing the process of transparency of budget information since 2018. [3] For this purpose:

- Launched the information portal "Open Budget", which provides reports on the state budget and budgets of state target funds, draft tax and budget policy, reports on the implementation of the state budget and budgets of state target funds, as well as the conclusions of the Accounts Chamber of the Republic of Uzbekistan;

- The information publication "Budget for Citizens" is published regularly. Currently, the information publication "Budget for Citizens" is dedicated to the parameters of the State Budget for 2018, 2019, 2020, and 2021, as well as "Budget for Citizens" for 2019 in Tashkent region. The form of information publication is designed to provide budget information in the form of infographics and tables, convenient and understandable to a wide audience (for all citizens);

- channels of budget information dissemination, as well as public involvement in the budget process (posting budget information on the official website of the Ministry of Finance and the telegram channel, organizing thematic seminars and roundtables, participation of representatives of the Ministry of Finance in television and radio broadcasting, media publications);
- The norms of ensuring the transparency of the budget process have been strengthened by legislation. From 2019, the ministries and departments, state trust funds, and the Fund for Reconstruction and Development of the Republic of Uzbekistan will distribute funds on a quarterly basis on their official websites by budget organizations under their jurisdiction; periodic financial statements; implementation of projects implemented at the expense of capital investments; recipients of subsidies and loans from state trust funds; post information on conducted tenders and public procurement.

- From 2019 (and from July 1, 2022 - at least $30 \%$ ) introduced a mechanism of citizen participation in the allocation of budget funds, which provides for the allocation of at least $10 \%$ of additional sources of district (city) budgets to activities formed on the basis of public opinion. By submitting proposals and voting on the information portal "Open Budget", citizens will determine the measures that, in their opinion, should be directed to funding from additional sources of local budgets. This mechanism is an important tool in attracting citizens to public finance management, as well as at the grassroots level in the implementation of ideas put forward through the portal "Open Budget".

It should be noted that our country has not yet been included in the international rankings "Open budget index" [4] and "Open budget survey" [5]. However, several countries in Central Asia, which are our neighbors, are included in this index. For example, according to the Open Budget Survey of the Kyrgyz Republic, the result is $63 \%$ out of $100 \%$. This means that the level of openness of fiscal policy in this country to the population is $63 \%$. In Kazakhstan, the figure is 58 percent, in Azerbaijan it is 35 percent and in Tajikistan it is 17 percent.

It should be noted that in the organization of these ratings are conducted various surveys of the population of the country, which are mainly based on the following 3 criteria.

- Budget transparency: The public availability, timeliness, and comprehensiveness of eight key budget documents that, according to internationally accepted good practice criteria for public financial management, all countries should publish at different points in the budget process. This section of the survey is used to calculate the Open Budget Index, whereby countries are given a score between 0 and 100 and ranked according to their level of budget transparency.

- Budget participation: The opportunities governments are providing to civil society and the general public to engage in the budget process, in order to contribute and influence decisions on how public resources are raised and spent.

- Budget oversight: The role and effectiveness of formal institutions (independent 
fiscal institutions, legislatures, and supreme audit institutions) to understand, monitor, and influence how public resources are being raised and spent.

Today, at the initiative of the President of our country, our budget system is also moving to a system based on transparency.

\section{MATERIALS AND METHODS}

We have tried to reveal the openness and transparency of the local budget, public budget, and budgetary system process through the initiative to researches local authorities' websites of the basic territorial level of Uzbekistan. For this purpose, preparatory work to develop criteria for openness and transparency of local budgets was carried out. The approaches and methods of different countries in their assessments were explored.

\section{ANALYSIS}

Today, the financial and economic literacy of the population of our country is growing through the portal "Open budget.uz", created by special decrees of the President. In addition, several types of socio-economic work have been carried out at the expense of certain types of funds or taking into account the needs and desires of the population.

Through the portal "Open budget.uz" you can get information not only on the state budget revenues, state budget expenditures, or local budgets but also on the initiative budget indicators, taking into account the views of the population of rural or urban areas lagging behind in development. through which their demands and wishes can be met.

All adult citizens of Uzbekistan have the right to propose projects based on public opinion in the budget aimed at improving their settlements and other issues. To leave proposals, the initiator of the project will be registered on the portal "Open budget" (open budget.uz). The next step is to fill out an online form on the Open Budget portal and submit an offer for the project. After that:

- All proposals for the submitted projects will be examined for compliance with the criteria approved by the Working Committee. The project excludes the possibility of resolving personal interests (car or home purchase, business support, etc.) and is worth $\$ 1$ billion. not more than UZS (not more than 4 thousand times the basic calculation amount). All projects are subject to economic and technical expertise by the authorities;

- Projects that meet the requirements of the approved criteria and have passed the economic and technical examination will be posted on the portal "Open Budget" for voting. During one selection cycle, a citizen has the right to vote only once for a single project;

- According to the results of the voting, the project with the highest number of votes in each district is declared the winner. Projects are selected from top to bottom based on the number of votes cast for them. Several projects in each district (city) can be declared winners. The total cost of the winning projects should not exceed the number of funds in the accounts of the "Fund of Citizens' Initiatives" in the relevant district (city);

- Based on the results of the voting, the Working Commission prepares a draft decision (order) on the financing of the winning projects. The decision (order) on the allocation of funds to finance the winning projects is approved by the Councils of People's Deputies;

- District (city) governments announce the winning projects and start their implementation;

- In the process of project implementation, the district (city) authorities publish monthly reports on their implementation and results in the media;

- At the end of each quarter, a report on the use of funds allocated for the financing of projects is submitted to the district (city) Council of People's Deputies. The district (city) Council of People's Deputies considers and approves the report on the use of funds allocated for the financing of projects of the open budget.

Based on the decision of the Working Commission, which summarizes the results of voting on projects on the portal, district (city) governments organize the process of conducting tenders for the implementation of works identified in the projects selected by citizens. The selection of contractors is carried out in accordance with the legislation of the Republic of Uzbekistan. Citizens who have selected the project and participated in its development are also actively involved in monitoring the implementation and implementation of the project.

The technology of implementation of open budget projects is that the idea of any project (of course, it has an author) must be supported by the public, the majority of the population in the voting process. The organizers provide an opportunity to promote initiatives from different communities. Initiators can be both citizens and groups of citizens united by the social character: people with disabilities and their families, veterans, children's, or youth organizations. Important point: a group of citizens does not have to be legally registered (have a legal entity and a bank account) to enter the project, but this condition is not excluded. Rules for the submission of similar proposals apply to urban and rural projects.

Today, the country has allocated a total of 530.50 billion soums for the initiative budget, taking into account the views of the population of each region and district. [6] It is gratifying that today a certain part of the budget expenditures is carried out taking into account the views, needs, and desires of the population. 
Table 1. [7]

Allocated initiative budget

\begin{tabular}{|l|l|l|}
\hline $\mathbf{O} / \mathbf{n}$ & Regions & The amount of allocated soums \\
\hline 1 & Tashkent region & 52315000000.0 soums \\
\hline 2 & Tashkent city & 69832000000.0 soums \\
\hline 3 & Syrdarya region & 19382000000.0 soums \\
\hline 4 & Surkhandarya region & 33238000000.0 soums \\
\hline 5 & Samarkand region & 39141000000.0 soums \\
\hline 6 & Republic of Karakalpakstan & 36965000000.0 soums \\
\hline 7 & Navai region & 26656000000.0 soums \\
\hline 8 & Namangan region & 33531000000.0 soums \\
\hline 9 & Khorezm region & 32077000000.0 soums \\
\hline 10 & Kashkadarya region & 48154000000.0 soums \\
\hline 11 & Jizzakh region & 26625000000.0 soums \\
\hline 12 & Fergana region & 41414000000.0 soums \\
\hline 13 & Bukhara region & 37282000000.0 soums \\
\hline 14 & Andijan region & 34159000000.0 soums \\
\hline & Total & 530771000000.0 soums \\
\hline
\end{tabular}

From the table above, it is clear that to date, the budget funds spent on initiatives approved by the majority of the population, selected from the initiatives proposed through the platform "Open budget. uz" form a large volume. To date, the total number of initiatives is 41,125 , the number of initiatives approved by the majority of the population is 22,967 , and the number of rejected initiatives is 18,158 . By the end of 2021 , the total number of votes is 1149499 .

Table 2. [7]

Allocated initiative budget for the districts of Namangan region

\begin{tabular}{|l|l|l|}
\hline $\begin{array}{l}\mathbf{O} \\
\mathbf{n}\end{array}$ & Districts & The amount of allocated soums \\
\hline 1 & Yangikorgan district & 1805000000.0 soums \\
\hline 2 & Namangan city & 4462000000.0 soums \\
\hline 3 & Kosonsoy district & 1836000000.0 soums \\
\hline 4 & Chust district & 10034000000.0 soums \\
\hline 5 & Mingbuloq district & 1779000000.0 soums \\
\hline 6 & Namangan district & 2039000000.0 soums \\
\hline 7 & Uchk'rgan district & 2069000000.0 soums \\
\hline 8 & Norin district & 1787000000.0 soums \\
\hline 9 & Uychi district & 1979000000.0 soums \\
\hline 10 & Pop district & 2136000000.0 soums \\
\hline 11 & Chortoq district & 1714000000.0 soums \\
\hline 12 & Turakorgan district & 1891000000.0 soums \\
\hline & Total & 33531000000.0 soums \\
\hline
\end{tabular}

In the second table, we can see the funds allocated to the districts and cities of Namangan region through initiative allocations and their amounts. These deductions According to the Decree of the President of the Republic of Uzbekistan No. PP-5072 dated April 13, 2021, [8] according to the Decree of the President of the Republic of Uzbekistan No. PP-5250 dated September 22, 2021 [9] and allocated from the district (city) budget. As can be seen in the table above, the largest allocations are in Chust district $(10,034,000,000.0$ thousand soums $)$, and the smallest allocations are in Chartak district $(1,714,000,000.0$ soums).
Initiative allocations show that the financial literacy of every inhabitant of our country is growing day by day, their lifestyle is gradually being implemented, taking into account their views and the most important of them.

\section{MAIN OUTCOMES AND FINDINGS}

There are many significant outcomes in this article. To be more precise,

- open budgetary helps to improve economic growth in every part of the country;

- populations opinions are tent to be one of the most important parts of the budget expenditure; 
- transparent budgetary shows the real power of the country in terms of financial side;

- it helps the regions and cities to attract foreigners to invest their money and set the new businesses there, it means new workplaces and jobs for local inhabitants.

\section{CONCLUSION}

To summarize, we may conclude that the budget system of Uzbekistan is in the developing stage and it is the stage that all populations of Uzbekistan are understanding the budgetary system of Uzbekistan. The first steps it takes on this path are related to the representation of this sphere in the information space. And if earlier the prevalence of traditional channels of information allowed shadowing it in local small mass media or being generally limited to the tools of citizens' appeals, the modern information society does not allow this to be done. The level of budget information transparency (the quality and volume of information about local budgets and finances) becomes an important criterion for assessing the appropriate level of public management and good governance.

As our research has shown, there is a significant positive link between the level of online openness of local budgets and key financial and socio-demographic factors. Following the line of this process of development, we guess we will manage to trace the evolution of open public budgetary publicity in Uzbekistan. Such studies will also allow finding out the weaknesses and objectively assessing the quality and volume of the budgetary and finance information presented online, which is an important factor in public relations and the local community development.

\section{REFERENCES}

1. On measures to ensure transparency of budget information and active participation of citizens in the budget process Resolution of the President of the Republic of Uzbekistan, PP - No. 1792 of August 24, 2018

2. On additional measures to ensure the active participation of citizens in the budget process Resolution of the President of the Republic of Uzbekistan, No. PP-5072 dated 13.04.2021

3. On measures to further expand the financing of public opinion events through the information portal "Open Budget" Resolution of the President of the Republic of Uzbekistan, No. PQ5250 dated 22.09.2021

4. Action Strategy for the five priority areas of development of the Republic of Uzbekistan in 2017-2021

https://www.uzavtoyul.uz/uz/post/presidentapproved-action-strategy-for-the-developmentof-uzbekistan.html

5. Online Openness and Transparency of Local Budgets in Belarus Yuri V. Krivorotko, Dmitriy V. Sokol
6. Budget transparency and fiscal performance Lucie Sedmihradska and Jakub Haas

7. Openbudget.uz https://openbudget.uz/oz Open financial reporting portal of Uzbekistan

8. Open budget index. An open budget survey https://www.internationalbudget.org/openbudget-survey/rankings Sites that compare the openness and transparency of the budget system of states. 